\title{
ON DIVERSITY, REPRESENTATION AND INCLUSION: NEW PERSPECTIVES ON THE DISCOURSE OF TOY CAMPAIGNS
}

\author{
Danielle Barbosa Lins de Almeida* \\ Conselho Nacional de Desenvolvimento Científico e Tecnológico - CNPq \\ Universidade Federal da Paraíba \\ Departamento de Línguas Estrangeiras Modernas \\ João Pessoa, PB, Brasil
}

\begin{abstract}
Toys have a playing purpose as well as a multi-functional dimension, as they relate to visual communication since their representations lead to unexpected practices by the child, which stimulates designers to be constantly exploring new ways of presenting their narratives to a double-audience of both parents and children. This article investigates how the discourse of toy campaigns has changed over the last decade, by focusing on the verbal and visual features of contemporary toy campaigns. It draws on the social semiotic approach of Kress \& van Leeuwen (2006) for the images' analyses and on cultural studies (BROUGÈRE, 2014) to provide a broader view on the issues of diversity, representation and inclusion. The analyses suggest that as diversity and the gradual breaking of gender boundaries have gained more visibility in children's media, we have been witnessing the disruption of existing narratives traditionally conceived in toy lines and campaigns.
\end{abstract}

Keywords: Toy. Campaign. Diversity. Narrative. Multimodality.

1 INTRODUCTION

Conventionally regarded as genuine expressions of children's culture, the notion that bequeaths to our contemporary concept of 'toy' is, in fact, a modern one that only started acquiring specificity from late $18^{\text {th }}$ century onwards. Prior to that, the term 'toy' was used to describe small pieces of art, miniaturised versions of everyday objects often made in "luxury materials such as gilded copper, ivory or silver" (FLEMING, 1996, p. 82) for wealthy adults' amusement (FLEMING, 1996). The transition to the current concept of 'children's plaything' was prodded by the manufacturing innovation of specialised industries and its marketing communication activity, which helped to consolidate a new sense of childhood and a consequent motif of children's culture by the closing decades of the $19^{\text {th }}$ century.

\footnotetext{
* Danielle Barbosa Lins de Almeida (PhD) holds a postdoctoral degree from the Universidad de Buenos Aires (UBA), where she worked as a visiting scholar in 2013. Her PhD research at Federal University of Santa Catarina included co-tutoring studies at the University of New South Wales in Sydney, Australia. She is currently an Associate Professor at the Department of Modern Foreign Languages at Federal University of Paraíba, Brazil. In 2015, Dr. Almeida was awarded a Scholarship of Research Productivity by the National Council for Scientific and Technological Development (CNPq) in Brazil. E-mail: danielle.almeida@gmail.com
} 
One of these motifs was the narrativised spectacle of the toy theatre (BENJAMIN, 1984; FLEMING, 1996), which emerged in $19^{\text {th }}$ century Europe as a form of entertainment for middle-class children, whose "evenings were often spent consigned to an austere playroom by absent parents" (FLEMING, 1996, p. 83). Soon the visual vividness of its miniaturised cut-out, colourful characters and backdrops started attracting more and more children and adding elements such as narrative and spectacle to the concept of 'toy'.

From miniaturised replicas of domestic objects to pleasant cut-out toy characters, with time and their specialised manufacturing, toys started gaining size and losing their minuscule and discreet character (BENJAMIN, 1984, my translation), which helped them achieve recognition in the social milieu, shifting their status quo of traditional craft products to specialised, mass-produced ones (FLEMING, 1996).

Alongside with the change of toys' status, a new imagery of childhood was being gradually constructed during the $19^{\text {th }}$ century, triggered by an array of children's products that permeated the catalogues and advertisements of the early pioneers of merchandising (KLINE, 1993). In a sense, the expanding market of children's cultural products was being developed around an emerging perception on childhood as an autonomous category that needed to attach specific 'tools' - such as balls, bicycles and dolls - as symbols of children's cultural and developmental requirements (KLINE, 1993, p. 59).

As cultural signifiers, toys have become symbols that not only convey "the common preoccupations of children with play but also their changing experience of things" (BARTHES, quoted in KLINE, 1993, p. 59), given that toys are endowed with social dimensions that go beyond their material spectrum.

Mediated by advertising discourse through modern narratives that include YouTube videos and images in social networks such as Facebook, toys can be 'textualised' in various ways, from cartoons to comic strips, as they consist of "both already produced communications and tools to produce communications with" (CALDAS-COULTHARD; van LEEUWEN, 2001, p. 96).

Nevertheless, for very long toys' enacted representations have been neglected by academic scholars, in being conventionally conceived of as ordinary, everyday entertainment objects to be manipulated by children during their free time.

For this reason, this study draws on the aspects of the Grammar of Visual Design by Kress \& van Leeuwen (1996) to address some of the cultural dimensions encapsulated in the discourse of toy campaigns, through the discussion of the stereotypes commonly identified in their narratives, such as advertisements, packaging and online campaigns.

\section{STEREOTYPES IN TOYS' DISCOURSE}

Not until very recently, representatives of toy companies have gathered together in order to discuss how to break traditional stereotypes in children's media and toys through the creation of narratives and products that somehow reflect new social realities.

From contemporary Disney characters showcasing girls as strong heroines to campaigns that help inspiring girls to go for their ideals, it can be observed that representations in today's media have been trying to revamp conventional standards that accounted for the so-called 'epidemic of invisibility' (SMITH; CHOUEITI; PIEPER, 
2016), a term used to refer to the lack of gender, ethnical, social and cultural representation in mainstream media.

To include diversity in toys' discourse, it must be said, can be considered a challenge, since toys tend to reveal a great deal about the conceptions and representations of a culture, and by doing so, it becomes necessary to "undo the systems of exclusion so as to open up new spaces for the multiple ways of being a subjects in a given culture, in a given historical time" (CRUZ, 2011, p. 42, my translation).

Let us take the example of adapted dolls - both for boys and girls - reflecting children with special needs. In terms of number and variety, they are still very few when compared to the prevailing, traditional standardized doll with a well-built body and straight, blonde hair, light skin and blue eyes that fills up the shelves of our toy stores.

Figure 1 - Adapted dolls from the \#ToyLikeMe campaign

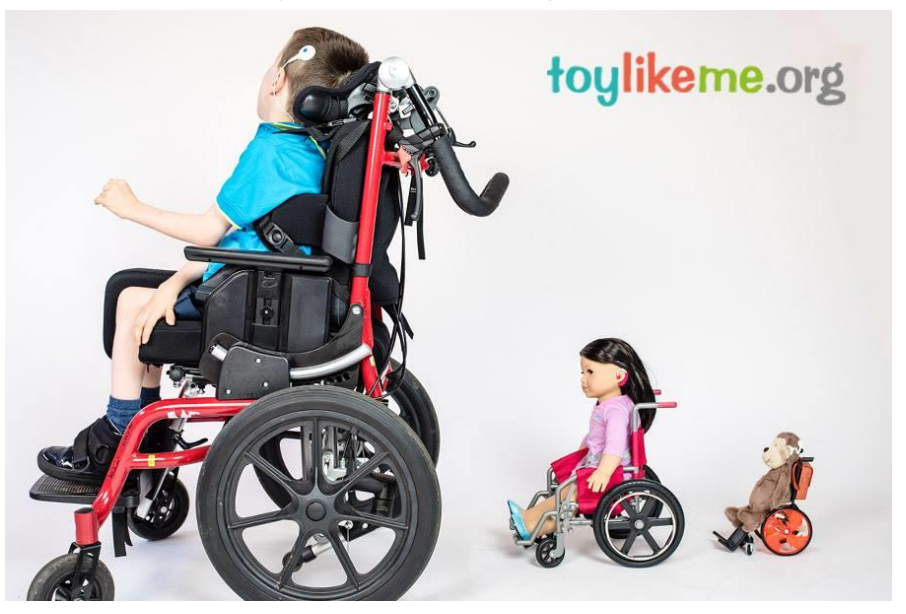

That being the case, whenever one single model is chosen as the representative of an aesthetic ideal, such model becomes naturalized and socially regarded as 'better' than any other mode of subjectivization. Choosing a stereotyped aesthetic model as the representative doll of a particular culture may be particularly inappropriate in places where such models are not the ones prevailing, as it seems to be the case of Brazilian doll Susi. In a previous study on the discourse of toy campaigns, Almeida (2006) argues that Susi's stereotype is far from representing the genuinely Brazilian girl, taken that her physical representation does not call for what is in fact seen in the country. Neither does her name seem to convey an authentic expression of the Brazilian culture, as the name Susi is by no means a common name in Brazil. Likewise, in a visit paid to Susi's toy manufacturer Estrela in 2004, Almeida (2006) could notice that blonde Susi was far more preferred to other models of the doll, such as its black version Susi Daiane dos Santos or the dark-haired or red-haired ones.

Cruz's (2011) more recent experiment with primary school children at the context of a public institution in the Brazilian southern state of Rio Grande do Sul allows us to substantiate some of these perceptions on stereotypes in toys' discourse. At the occasion of the experiment, children were given a collection of 'different' male and female dolls to play with: black, elderly, obese, disabled, wheel-chair users, pregnant, Downsyndrome dolls. The idea was to verify how the offer of such diverse toys to 7-8-year-old 
children influenced their discursive choices and practices while interacting and playing with these dolls.

Twenty-four (24) children - thirteen (13) boys and eleven (11) girls - were shown what the researcher has called an "Enchanted Suitcase" carrying twelve (12) female dolls and six (6) male dolls with all sorts of special needs and of different stereotypes. In their interaction with these dolls, children produced discourses of strangeness and discrimination showing that they, too, sometimes get impregnated with cultural prejudice inasmuch as religion, gender, ethnicity and generation issues are concerned.

This was particularly the case of children playing with the Down-syndrome baby doll as well as the red-haired and black dolls. According to the researcher, the discourse of strangeness occurred mainly due to children's lack of exposition to cultural diversity through dolls by the media and toy producers, since, as aforementioned, the offer of a single aesthetic, ethnic and/or generation model ends up perpetuating a hegemonic and standardised view of society.

In relation to children's discursive choices, it could be verified that they often referred to the dolls' hair and skin colours in a way that sounded prejudicial as they seemed to give preference to playing with the light-skinned dolls with straight hair and not with the dark-skinned ones with curly or with an Afro-type of hair. Discourses like "This doll is too old", "This doll's hair is ugly and of a bad type (ruim)" seem to reveal these children's prejudice insofar as their interactions with the black dolls was involved. Also, discourses like "This baby is strange! It has something on his/her face", "Her eyes are different" or "Her tongue is almost outside her mouth" to refer to the Downsyndromed baby doll seem to point out to a discourse of discrimination, exclusion and strangeness that reveal children's lack of familiarity with what is (still) not common to their eyes (p. 49, my translation).

On the other hand, markers of acceptance and receptiveness appeared in these children's discourses whenever they referred to the Barbie doll and Disney's princesses. Discourses like "Barbie's is the coolest doll ever" and "I like this princess because she has very long hair" have been interpreted by Cruz (2011) as reflections of a hegemonic and Eurocentric thought which substantiate the signs of 'normality' spread as common truths along the $20^{\text {th }}$ and $21^{\text {st }}$ century (p. 49, my translation).

Other hegemonic stereotypes have been associated to signs of aggressiveness in action dolls for boys materialized in their strong, flexible bodies, allowing these dolls to make certain movements many times restricted in female dolls. This has been widely discussed in Almeida's (2006) study:

[...] boys' dolls (are) usually located 'out there' and (are) endowed with flexibility to move sideways, open their legs, hold objects and stand by themselves without falling (ibid.). Contrastively, girls' dolls are commonly represented living "entirely in [their] own enclosed world" (FLEMING, 1996, p. 53) and (are) kinetically designed to be restricted in their action potentials.

\footnotetext{
${ }^{1}$ Children's discourses have been translated from their original language, Portuguese. The translation into the English language remains under my responsibility.
} 
Be that as it may, experiments like the ones conducted by Cruz (2011) and Almeida (2006) may be a starting point of reflection for the discussion about the lack of diversity historically verified in toy campaigns. Not only does such lack of diversity exclude those who do not fit in with the standardized social aesthetic models but it also reduces the possibilities of integrating the differences from an early age in childhood which may, in turn, minimize the distance that separates an idealized childhood from the real one.

\section{TOYS AND THE CELEBRATION OF DIVERSITY}

As it has been pointed out before, for quite a long time toy producers seemed to underestimate the need to include diversity in toys' discourse - especially dolls' - as the only model available in the toy shelves was the unrealistically beautiful 57-year-old Barbie or rather similar dolls that were close to perfection in terms of physical appearance.

Once the discourses of acceptance and inclusion started to frequently appear in the social media, mainstream toy companies like Mattel felt the urge to incorporate a more realistic range of body-diverse dolls in their lines, with a view to reflecting real life diversity into toys' material configurations.

One of the first toy producers to do so was artist and researcher Nickolay Lamm, founder of the Lammily line of dolls. Through a crowd-funding campaign launched in $2014^{2}$ under the slogan "Average is beautiful. Real is beautiful", Mr. Lamm based Lammily doll's proportions on an actual teenage woman with flexible material properties to open her legs, move her wrists, knees, elbows and feet.

\section{Figure 2 - Lammily doll with realistic body proportions}

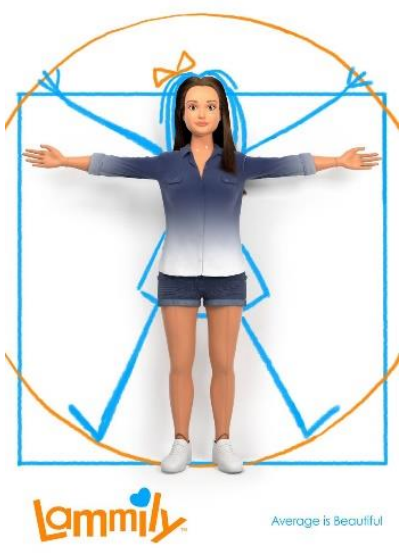

As aforementioned, limitation in dolls' movements has for long been addressed by toy researchers, as containing certain gender meanings commonly associated with a submissive view of women in society (ALMEIDA, 2006).

\footnotetext{
${ }^{2}$ Lammily's campaign managed to raise $\$ 95.000$ through crowdfunding tool CrowdtiltOpen.
} 
Because of their inability to stand up, hold anything in their hands or move their heads in any direction, dolls like Barbie and Brazilian Susi were believed to reinforce a passive depiction of women through their semiotic representations, in spite of their dynamic, narrative visual depiction (ALMEIDA, 2006) in online advertisements, usually picturing them performing activities like going to work, doing sports, going shopping, etc. Restricted as their material properties might have traditionally been, in recent years, alongside with the inclusion of a more diverse line of realistic dolls, toy producers have also been concerned with the idea of adding more flexible material properties to dolls' design, probably as another way of reflecting the social changes women have been going through in contemporary society, which, in turn, has increased the modality value of their representations.

\section{Figure 3 - New material properties in dolls' design}

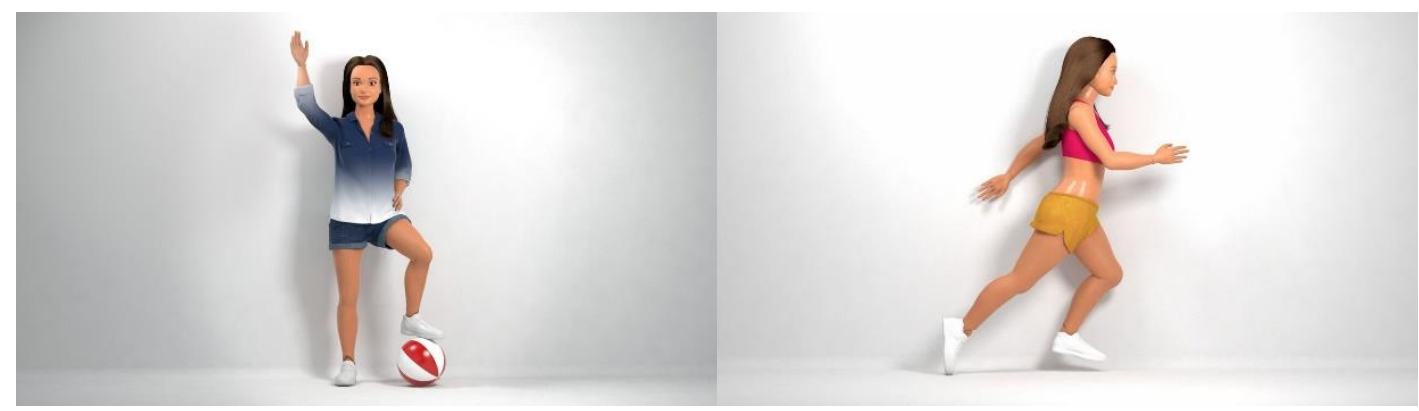

To attest to the increasingly modality value in dolls' representation, flash forward to 2016, we can see ordinary women's body shapes being proportionally adjusted to fit dolls' bodies as well as marks of 'imperfection' adding realism to dolls like the Lammily doll in analysis, whose scars, stretch marks, cellulite, acne and period patches emulate the representation of a real teenager. The idea, says its producer, is to make children relate to these dolls, as a way to develop their self-esteem and enact a more positive body image, despite their little imperfections (adapted from Lammily official website).

In Lammily's official webpage, one of the images depicts a black girl holding a white Lammily doll while both stare at her bruise under a green Band-Aid patch, in a reactional sort of visual narrative depiction, while their figures are made more salient contrasting with a light-green slightly contextualized background (Figure 4). On the righthand-side, in the New space, the insertion of a strongly framed sticker box containing Lammily's marks such as scars, stretch marks, cellulite and acne, calls the viewer's attention as a separate piece of visual information at 'issue'. The doll's accompanying accessories seem to remind the child viewer that both the doll and the girls who play with it share the experience of being prone to incidents of this nature, as if they belonged to the same 'world' of teenagers. 
Figure 4 - The creation of solidarity in the verbal and visual texts from Lammily's official webpage

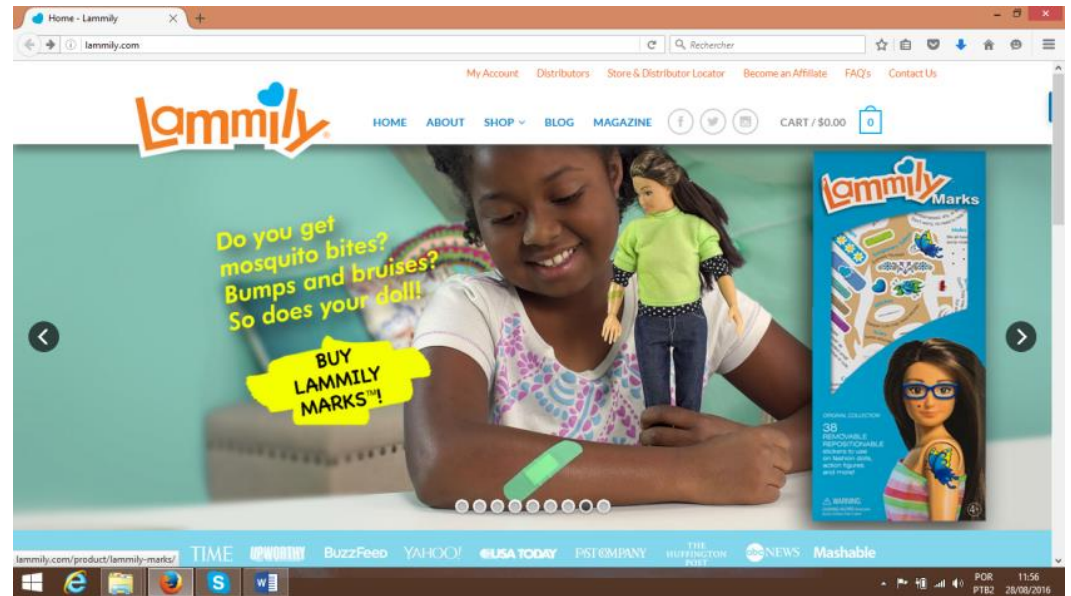

Interactively, closeness and proximity are visually conveyed by their offer kind of gaze and their eye-level depiction through a medium, vertical angle, which point to power equality in relation to the viewer, positing to an attitude of friendship to be established with him/her. Indeed, the use of an eye-level gaze and medium shot angles have been particularly associated to toy campaigns in that they seem to foster an attitude (s) of empathy with the viewer - in this case, the child - through power equality, which, ultimately, helps fostering consumption, the ultimate goal of advertising (Almeida, 2006).

Besides the way the text is visually constructed in order to create a sense of solidarity with the child, the verbal text also seems to reinforce the need to bring the represented participants - the black girl and the Lammily doll - closer to the interactive participant - the child - who is viewing the advertisement. This interpersonal closeness between addresser and addressee is verbally instantiated, for example, by means of direct interaction with the reader, through the use of questions and the pronoun you, as the verbal text in Lammily's webpage highlights in yellow letters: Do you get mosquito bites? Bumps and bruises? So does your doll! Buy Lammily's Marks!

\section{4 'WE ARE MANY': TOWARDS NEW DOLLS' REPRESENTATIONS}

The attempt to offer choices instead of dictating a single standard to be followed seems to be the trend in the toy market of our times. Taking as an example the American Girl 2016 campaign, it is possible to see 40 (forty) dolls of the same type, wearing the same light purple outfit, symmetrically arranged across the pictorial space in a conceptual, classificatory, covert taxonomy type of visual structure, as if they were products of the same type (KRESS; VAN LEEUWEN, 2006; LEWIS, 2001; UNSWORTH, 2001). 
Figure 5 - American Girl Truly Me ${ }^{\mathrm{TM}}$ line

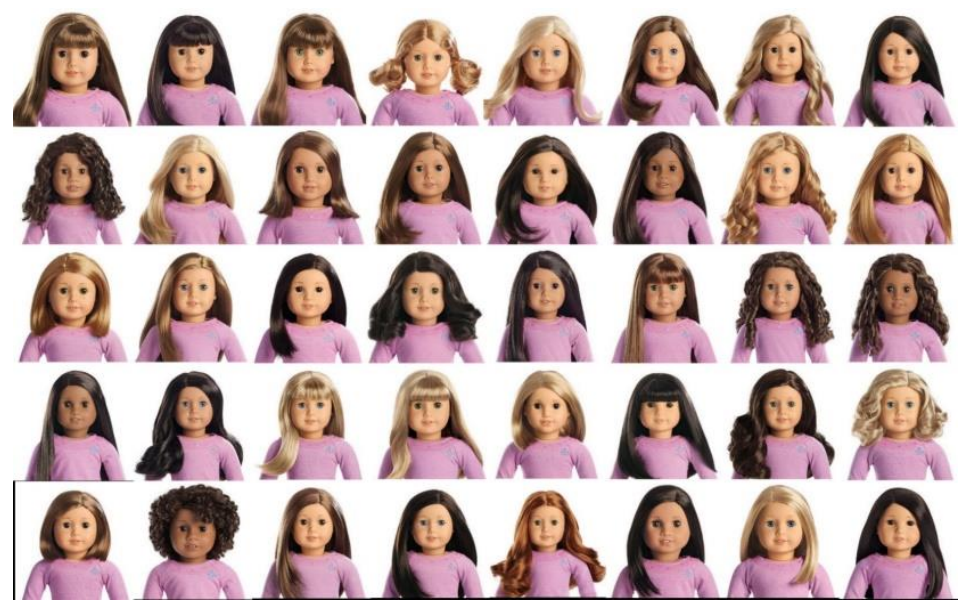

Strong engagement is fostered by the use of a demand type of gaze as well as the depiction of the dolls in a close-up, revealing the details of their faces, which seem to reflect the various possibilities of hair colour, style and skin and eye colour, promoted by the American Girl Truly Me ${ }^{\mathrm{TM}}$ line. In their official site, a text reads: "American Girl's mission is to celebrate girls. We embrace who they are today and look forward to who they will become tomorrow".

Lexicogrammatical choices for processes (HALLIDAY, 1978) like "celebrate girls", "embrace who they are today" and "look forward to who they will become tomorrow" foreground the same sense of rupture with pre-established social values and behaviour observed in Almeida's 2006 study on toys, whereby the absence of fixed aesthetic parameters to portray the multiculturalism of a country like the United States was encapsulated in The Bratz' semiotic representation. The multi-ethnicity of the Bratz was believed to be marked in their different skin tones, hair type and clothes, thus reflecting a sort of racial classes. Through the verbal and visual texts available in their official website back in 2003, the producers of the Bratz dolls' marketed language seemed to convey significations like the celebration of independence through puns like celeBratzion and independAnce located at the upper space of one of their advertisements, by inviting girls to become part of their "team" of ethnically diverse dolls.

Back then, the Bratz' producers argued that these dolls' looks epitomised the multiculturalism rooted in the North-American society, since their big-sized heads and eyes, protuberant lips and unrealistic popped-off feet did not resonate an idealized, fixed aesthetic parameter. In his interview to The Week back in 2004, Bratz' toy producer Isaac Larian contended that The Bratz echoed "all races and ethnic cultures, from white to black, Asian, Jewish and Hispanic" $\left(10^{\text {th }}\right.$ January 2004). They were also believed not to dictate any aesthetic 'prop', as their exaggerated looks, disproportionate body measures allowed "girls of all shapes and sizes see themselves reflected in their mirrors".

In a sense, the same pattern seems to be repeating in the American Girl Truly Me ${ }^{\mathrm{TM}}$ campaign, taken that diversity and representation are also being celebrated both visually and verbally. At the visual level, the articulation of a close-up shot, a demand kind of gaze and the absence of framing lines connecting all forty American Girls together corroborate a sense of group identity, despite their differences. At the verbal level, the 
same sense of identity is fostered by a text that reinforces the celebration and acceptance of the differences: "American Girl's mission is to celebrate girls. We embrace who they are today and look forward to who they will become tomorrow".

5 NEW FAMILIES, NEW TOYS

One cannot deny the profound effect of the media in early childhood. Studies have shown that children start discovering gender constructions as from the age of 3 years old and that by the time they reach 8 years old, they have learned to define themselves in relationship to or in context of the opposite sex (NANKANI, 2016)

In this sense, the presence of sexist marks of gender on contemporary toys has criticized in mainstream media, as it seems to restrict children's choices of what to play or not play with. Terms like "gender-neutral toys or toy packaging" have been used by advertisers to refer to the removal of gender-based labelling that defines who will ultimately play with a certain toy. Whereas branded toys for either boys or girls were less than $2 \%$ in the 1970 's, now they seem to be the norm, according to Dinella's (2014) study about (non) gender-typed toys and how they affect boys' and girls' judgments of the toys.

One example of the disruption of traditional narratives conceived in toy lines and campaigns seems to be that of MyFamilyBuilders ${ }^{\mathrm{TM}}$ toy set online campaign, a brand that takes pride in creating "a world where parents and kids celebrate love and the values shared by all families, regardless of their color, creed, sexual orientation or culture" (MyFamilyBuilders ${ }^{\mathrm{TM}}$ official website).

Figure 6 - MyFamilyBuilders ${ }^{\mathrm{TM}}$ toy set package

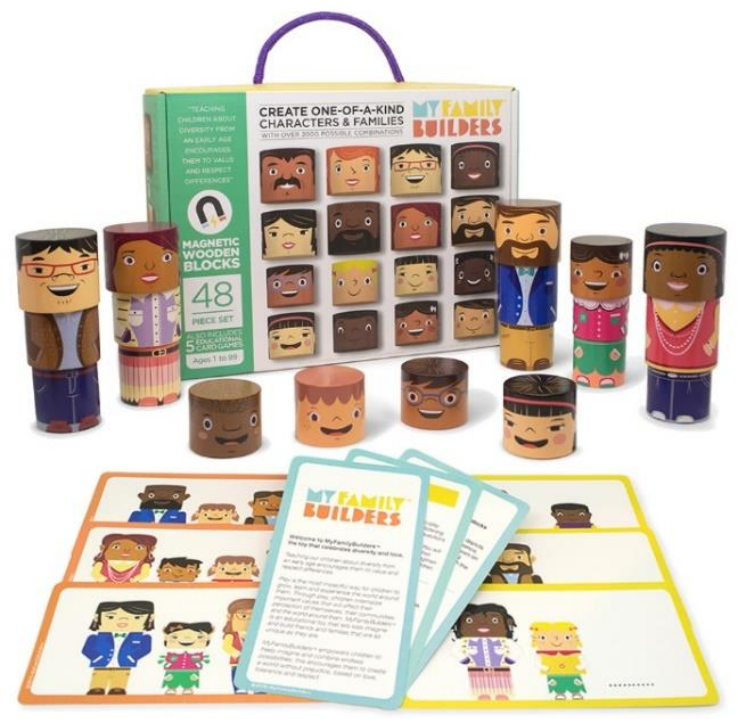


Aimed at early-childhood infants, this educational toy set encourages children to build their characters and families as they wish, as it contains 48 wooden pieces that snap together with concealed magnets and a board game with 25 cards that allow for a total of 2.048 possible matches per set. Important to notice that not all of the wooden blocks are the same size, as children can build characters that are taller or shorter, chubbier or thinner.

At the visual level, one of the advertised images available in MyFamilyBuilders official website portrays a non-traditional family structure with only four units from the kit: two mothers take the central position in the picture, accompanied by their daughter and son, displayed at the right-hand and left-hand side, respectively. As far as its compositional meaning goes, the way the couple is displayed in the foreground of the picture, emphasises their centrality and conspicuousness in terms of size proportion in relation to the other characters. This evidences their salience against the light-green background and attests to the fact that the 'different' elements were really meant to be made more eye-catching to the viewer in this picture. The smile on their facial expression and demand type of gaze also call for solidarity and an attitude of empathy with the viewer, conveyed through power equality, as if they were saying: "I'm also like you".

Figure 7 - New families in the toy package

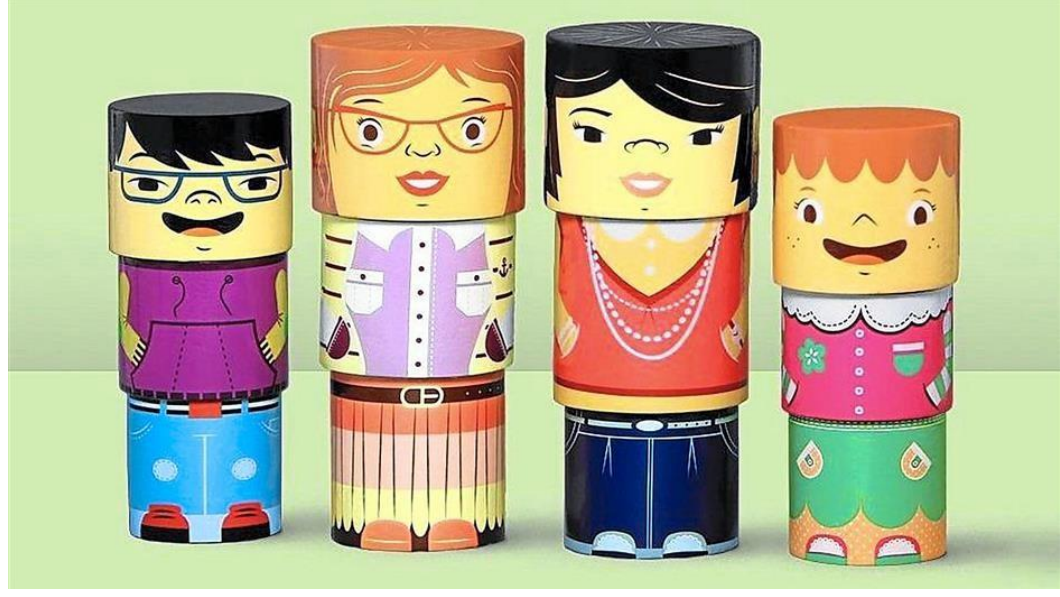

By showing this sort of campaign, toy makers believe to be celebrating the differences, removing prejudice and opening children's eyes to a world of possibilities, once the set reflects the nature of some of the families of our days, regardless of their sexual orientation, gender identities and multiple sets of parents.

\section{LET'S PUT DIVERSITY IN THE TOYBOX: DISABILITY TOYS}

While researchers have been discussing the lack of representation in mainstream media, it is important to mention that the so-called 'epidemic of invisibility' (SMITH, CHOUEITI; PIEPER, 2016) has also affected children with disabilities, since not until very recently, there were virtually no disability-themed toys, until the appearance of the Three Blind Mice Talking Toy in 1955. 
With respect to this, it is not surprising to realize that recent campaigns such as \#ToyLikeMe, showcasing disability toys reflect a more disability-inclusive society, as they seem to have an impact on the self-esteem of children with disabilities and to arouse a positive reaction from their parents.

The \#ToyLikeMe campaign was founded in 2015 by Karen Newell, a play consultant and former children's television researcher, together with her partially deaf and partially sighted journalist friend Rebecca Atkinson, in order to display disability toys and give emphasis to socially-relevant events on the issue of inclusion. Prior to the launching of the \#ToylikeMe campaign other attempts to include disability toys had been made back in the 1980's, such as Mattel's Cabbage Patch style dolls with disabilities and Helga Parks Down Syndrome Dolls. At that time, however, the reception was primarily negative.

The gradual visibility that disability toys have been gaining in digital spaces might be showing us that "we are in the midst of a significant shift towards an inclusive world view of disability" (ELLIS, 2015), as we seem to be getting more exposed to the "reality of disability' in society, Ellis contends. She believes that children's toys are linked to both transitory and concrete values, the former being related to the fades and trends of the time they were produced, and the latter, related to the everlasting effect they have in terms of their ideological purpose.

An epitome of inclusion in toys' discourse, the selected \#ToyLikeMe campaign portrays six different dolls, in different sizes, sharing the same pictorial space, against a plain, decontextualized background, which highlights their colourful looks. Each doll carries a special need, such as the Tinker Bell with a cochlear implant and the wheelchairusing doll holding a sign that reads: Join the toy box revolution!

\section{Figure 8 - \#ToyLikeMe campaign}

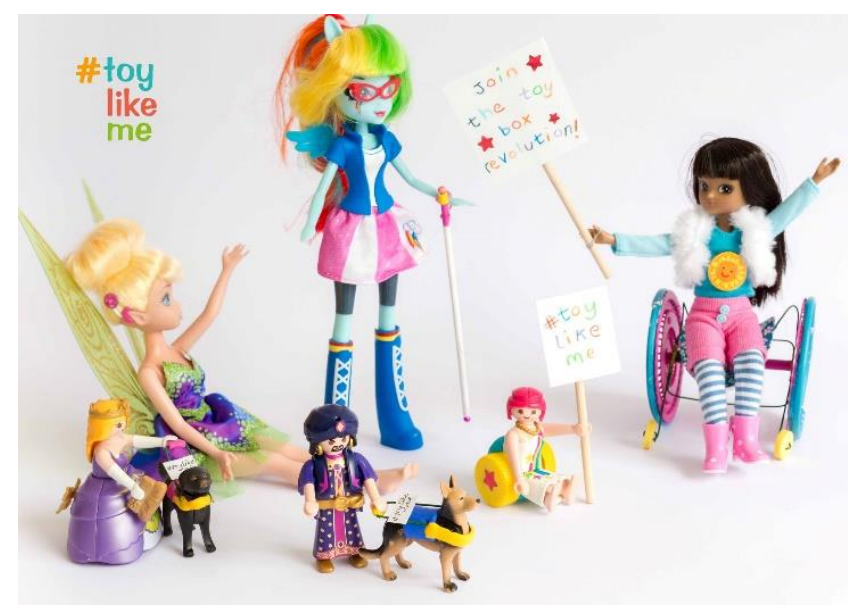

Other toys in the campaign also carry a powerful ideological meaning despite their smaller proportions, such as the visually-impaired Playmobil figures being led by guide dogs for the blind and the female Playmobil figure in a wheelchair. Occupying the central 
position in the pictorial space is the colourful doll My Little Pony Equestria Girl from Hasbro carrying a walking stick and wearing knee-high boots.

Relevant as this representation certainly is in terms of visual choices, it is important to mention that none of the pictured dolls seem to establish a direct rapport with the reader via demand gaze, although solidarity does get invited by means of other codes such as the placement of the dolls grouped together on a conceptual, classificational basis, as members of the same class who share the same kinds of needs, which is believed to foster identification and involvement with the reader.

Another aspect used in the campaign in order to construct solidarity between addresser and addressee as well to create interpersonal closeness between them, refers to the ways language choices are used: the use of imperative statements such as Join the toy box revolution! not only establishes a direct interaction with the addressee, by enhancing a higher degree of intimacy with him/her, but also acts as a persuasion tool in evoking closeness with him/her, who is directly invited to be part of the group, whose reality is visually represented in the image.

All in all, what campaigns of this kind seem to be calling us for is to look with more 'inclusive' eyes to these children's world, which, for very long, got invisible from the perspective of the media. By neglecting to represent the impaired and/or the different or by stereotyping their representation, media has failed to give disabled children the chance to be portrayed in a more positive fashion and not as a group whose needs have to be suppressed, overcome or faced with embarrassment. What these groups need, in fact, is to be semiotically portrayed as real people, whose representations, let us hope, will be gradually naturalized in a near future.

\section{FINAL CONSIDERATIONS}

This article has aimed to bring to the forefront of analysis current trends in toy campaigns by approaching the stereotypes and comparing them with what can be verified in children's media today. That includes contemporary toy campaigns which have managed to incorporate the so called discourse of the 'invisible' by adding narratives of diversity and inclusion in their lines, as it is the case of toy companies such as American Girl TM, Toy Like Me ${ }^{\mathrm{TM}}$, Lammily ${ }^{\mathrm{TM}}$ and My Family Builders ${ }^{\mathrm{TM}}$.

By focusing on some of their verbal and visual aspects, the analysis has mainly resorted to the systems of significations offered by Kress \& van Leeuwen's (2006) multimodal approach as well as on some references from the area of cultural studies to account for the discussion of the social context in which these toys are inserted.

The analyses have pointed to the beginning of a transition in terms of toys' media representations, in that contemporary toy campaigns seem to be gradually turning their attention to the new configurations of being a child nowadays, which includes having different family structures, accepting physical imperfections as well as naturalizing the way we look at disabilities. 
ALMEIDA, D. B. L. Icons of Contemporary Childhood: A Visual and Lexicogrammatical Investigation of Toy Advertisements. Unpublished_PhD Dissertation - Universidade Federal de Santa Catarina, Florianópolis, 2006.

BENJAMIN, W. Reflexões: a criança, o brinquedo e a educação. Tradução de Marcus Vinícius Mazzari. São Paulo: Summus. 1984.

BROUGÈRE, G. Toys or the Rhetoric of Children's Goods. In: Machin, D. (ed.). Visual Communication Series: Handbooks of Communication Science [HoCS] Vol. 4. Berlin: DeGruyter Mouton. 2014.

CALDAS-COULTHARD, C. R.; LEEUWEN, THEO VAN. Stunning, Shimmering, Iridescent: Toys as the Representation of Gendered Social Actors. In: LITOSSELITI, L.; SUNDERLAND, J. (Eds.). Gender Identity and Discourse Analysis. Amsterdam: John Benjamins, p. 91-108, 2002.

CRUZ, M. B. Bonecas, diversidade e inclusão. Rev. Psicopedagogia, v. 28, n. 85, p. 41-52, 2011.

ELLIS, K. Disability and Popular Culture: Focusing Passion, Creating Community and Expressing Defiance. Fanham, Surrey: Ashgate, 2015.

FLEMING, D. Powerplay: toys as popular culture. Manchester: Manchester University Press, 1996.

JEWITT, C.; OYAMA, R. Visual Meaning: a Social Semiotic Approach. In: Handbook of Visual Analysis. London: Sage, 2001.

KLINE, S. Out of the Garden: Toys and Children's Culture in the Age of Marketing. London: Verso Press, 1993.

KRESS, G.; VAN LEEUWEN, T. Reading images: The Grammar of Visual Design. London: Routledge, 1996.

LEWIS, D. Reading Contemporary Picture Books. London: Falmer. p.145-167. (Appendix 2 Gunther Kress \& Theo van Leeuwen's Grammar of Visual Design), 2001.

NANKANI, S. What Toy Makers are Doing about Gender and Diversity. Available on <http://www.joanganzcooneycenter.org/2016/05/10/what-toy-makers-are-doing-about-gender-anddiversity/>.

SMITH, L. S.; CHOUEITI, M.; PIEPER, K. Inclusion or invisibility? Comprehensive Annenberg Report on Diversity in Entertainment. Media, Diversity, \& Social Change Initiative. Institute for Diversity and Empowerment at Annenberg, University of South California, 2016.

UNSWORTH, L. Describing Visual Literacies. In: Teaching Multiliteracies across the CurriculumChanging contexts of texts and image in classroom practice. Philadelphia: Open University Press, p. 71 112,2001

WEISGRAM, E. S.; FULCHER, M.; DINELLA, L. M. Pink gives girls permission: Exploring the role of explicit gender labels and gender-typed colors on preschool children's toy preferences. Journal of Applied Developmental Psychology, n. 35, p. 401-409, 2014.

\section{ACKNOWLEDGMENTS}

This article is part of a project entitled Toys on Focus |Brinquedos em Foco, sponsored by the National Council for Scientific and Technological Development (CNPq), within the category Scholarship of Research Productivity.

I would also like to thank toy companies American Girl TM, Toy Like Me ${ }^{\mathrm{TM}}$, Lammily $^{\mathrm{TM}}$ and My Family Builders ${ }^{\mathrm{TM}}$, for understanding the scientific nature of my study and allowing me to reproduce the toys' images used in this article.

Recebido em: 16/12/16. Aprovado em: 11/07/17.

ALMEIDA, Danielle Barbosa Lins de. On diversity, representation and inclusion: New perspectives on the discourse of toy campaigns. Linguagem em (Dis)curso - LemD, Tubarão, SC, v. 17, n. 2, p. 257-270, maio/ago 2017. 
Título: Sobre diversidade, representação e inclusão: novas perspectivas no discurso de campanhas de brinquedos

Autora: Danielle Barbosa Lins de Almeida

Resumo: Os brinquedos têm uma função na brincadeira, bem como uma dimensão multifuncional, uma vez que se relacionam com a comunicação visual, pois suas representações conduzem as crianças a práticas inesperadas, o que estimula os designers a explorarem constantemente novas formas de apresentar suas narrativas a uma dupla audiência de pais e filhos. Este artigo investiga como o discurso das campanhas de brinquedos vem mudando ao longo da última década, focalizando as características verbais e visuais das campanhas de brinquedos contemporâneos. Baseia-se na abordagem semiótica social de Kress e van Leeuwen (2006) para as análises das imagens, e nos estudos culturais (BROUGÈRE, 2014), de modo a proporcionar uma visão mais ampla das questões de diversidade, representação e inclusão. As análises sugerem que, à medida que a diversidade e a ruptura gradual das fronteiras de gênero ganharam maior visibilidade nas mídias infantis, testemunhamos a ruptura de narrativas tradicionalmente concebidas em linhas e campanhas de brinquedos.

Palavras-chave: Brinquedo. Campanha. Diversidade. Narrativa. Multimodalidade.

Título: Sobre diversidad, representación e inclusión: Nuevas perspectivas en el discurso de campañas de juguetes

Autora: Danielle Barbosa Lins de Almeida

Resumen: Los juguetes tienen una función en los juegos, también una dimensión multifuncional, a vez que se relacionan con la comunicación visual, pues sus representaciones conducen los niños para prácticas inesperadas, el que estimula los designers a exploraren constantemente nuevas formas de presentar sus narrativas a una dupla audiencia de padres e hijos. Este artículo investiga como el discurso de las campañas de juguetes ha cambiado durante la última década, focalizando las características verbales y visuales de las campañas de juguetes contemporáneos. Se basa en el abordaje semiótica social de Kress y van Leeuwen (2006) para los análisis de las imágenes y en los estudios culturales (BROUGÈRE, 2014) de modo a proporcionar una visión más amplia de las questiones de diversidad, representación e inclusión. Los análisis sugieren que, la medida que la diversidad y la ruptura gradual de las fronteras de género han ganado mayor visibilidad en las medias infantiles, testimoniamos la ruptura de narrativas tradicionalmente concebidas en líneas y campañas de juguetes.

Palabras-clave: Juguete. Campaña. Diversidad. Narrativa. Multimodalidad.

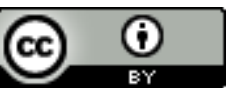

Este texto está licenciado com uma Licença Creative Commons Atribuição 4.0 Internacional.

ALMEIDA, Danielle Barbosa Lins de. On diversity, representation and inclusion: New perspectives on the discourse of toy campaigns. Linguagem em (Dis)curso - LemD, Tubarão, SC, v. 17, n. 2, p. 257-270, maio/ago. 2017. 